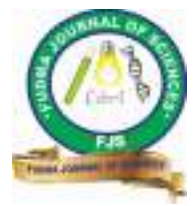

FUDMA Journal of Sciences (FJS)

ISSN online: $2616-1370$

ISSN print: 2645 - 2944

Vol. 4 No. 3, September, 2020, pp 624-630

DOI: https://doi.org/10.33003/fjs-2020-0403-409

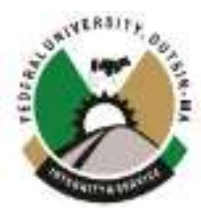

\title{
BIO STIMULATORY INFLUENCE OF COMPOST AND INORGANIC FERTILIZER ON BACTERIAL DEGRADATION OF SPENT ENGINE OIL CONTAMINATED SOIL
}

\author{
${ }^{1}$ Adeleye, A. O., ${ }^{* 2}$ Onokebhagbe, V. O., ${ }^{1}$ Akindiya, A. J. and ${ }^{2}$ Nkereuwem, M. E. \\ ${ }^{1}$ Department of Environmental Sciences, Federal University Dutse, Dutse, Jigawa State, Nigeria; \\ ${ }^{2}$ Department of Soil Science, Federal University Dutse, Dutse, Jigawa State, Nigeria. \\ ${ }^{*}$ Corresponding Author's Email: victor.onokebhagbe@gmail.com, +2348029880771
}

\begin{abstract}
The harmful effects of spent engine oil on aquatic and terrestrial ecosystems have been well established in literature. This study was conducted to assess the bio stimulatory influence of amendments; compost and inorganic fertilizer on bacterial degradation of spent engine oil contaminated soil. $500 \mathrm{~g}$ of unpolluted soil was collected and artificially contaminated with 5,10 and $15 \%(\mathrm{v} / \mathrm{w})$ spent engine oil. The experiment was laid out in a completely randomized design. Each amendment $(50 \mathrm{~g})$ was subsequently mixed thoroughly with the spent engine oil contaminated soil at varying levels except nine experimental bottles used as control. Incubation study was carried out and lasted for four weeks. Estimation of total petroleum hydrocarbon, $\mathrm{pH}$, electrical conductivity, temperature and bacterial population density was done within two weeks interval during the incubation study. Results obtained indicate that compost significantly enhanced total petroleum hydrocarbon reduction by $87 \%$ while inorganic fertilizer facilitated $62 \%$ total petroleum hydrocarbon reduction on $5 \%$ spent engine oil contamination level respectively. Estimation of hydrocarbon utilizing bacteria on 5, 10 and $15 \%$ spent engine oil contaminated soil indicated that compost enhanced higher hydrocarbon utilizing bacteria thereby influencing bacterial degradation than those stimulated with inorganic fertilizer. $\mathrm{pH}$ remained in the range of alkalinity (7.8 and 8.06) for compost and 6.2 and 6.7 for inorganic fertilizer. The potential that compost recorded in influencing bacterial degradation of spent engine oil contaminated soil in this study has made it a good bio stimulant for the bioremediation of hydrocarbon polluted environments.
\end{abstract}

Keywords: Bioremediation, Cocoa pod husk, Inorganic fertilizer, Total petroleum hydrocarbon, Bacteria.

\section{INTRODUCTION}

The application of biotechnological processes entailing the employment of microorganisms with a view to preferring solutions to environmental pollution problems are fast growing these days. According to Pala et al. (2006), bioremediation processes involve the employment of microorganisms coupled with supplementation with desirable nutrients to expunge environmental pollutants from soils, water and sediments. Biostimulation is a feasible option owing to the fact that it is cost effective, manageable and environment friendly (Funmilayo et al., 2016). Although numerous research studies (Sathishkumar et al., 2008; Nievas et al., 2007; Zhang et al., 2010; Farag and Sulaiman, 2011; Jain and Bajpai, 2012) have been conducted and reported over the years on bacterial degradation with a view to tackling the problem of oil contamination, these reports, however, have been limited to scientific approaches that local farmers do not freely have access to or may not be able to comprehend the technicalities involved.

A bio stimulatory study conducted by Yerima et al. (2011) on the potential of some organic wastes in enhancing bacterial salvage of crude oil contaminated soil showed that sewage sludge produced the best performance compared with other organic supplementations; chicken droppings and cow dung utilized. These authors further reported that the achievement that sewage sludge recorded in their study might be connected to its capability to improve porosity of the soil thereby facilitating the movement of desirable nutrients and gases. This submission was seconded by Kamaluddeen et al. (2016) in their biostimulatory study involving the effect of processed sewage sludge in the clean-up of engine oil contaminated soils. These authors established that even though sewage sludge produced a significant effect in the provision of essential nutrients that assisted bacterial growth which ultimately led to the consumption of hydrocarbons by the microorganisms in the system, vast concentrations of heavy metals that might have originated from the sewage employed or engine oil were documented.

A similar study conducted and submitted by Osazee et al. (2015) on the feasibility of cow dung to stimulate bioremediation of crude oil contaminated soils showed that the organic waste employed at varying weights was successful in biostimulating the fungal species in the contaminated soil as microbial population was significantly enhanced. Owing to the remarkable influence of organic waste products in enhancing biodegradation rate of microbial consortium involved in various bioremediation research studies documented in the literature, this study was staged to assess the comparative influence of compost and inorganic fertilizer on bacterial degradation of spent engine oil contaminated soil. 


\section{MATERIALS AND METHODS Collection of samples}

Random sampling method was used for the collection of composite soil samples from the permanent site of Federal University Dutse campus (Lat. $11^{0} 46^{\prime} 39^{\prime \prime} \mathrm{N}$ and Long. $9^{0} 20^{\prime}$ 30 "E), Dutse, Jigawa state. Spent engine oil was sourced from one of the service pits in mechanic village Dutse. Compost was collected from a stock of already composted cow dung (CD) and cocoa pod husks (CPH) described by Adeleye et al. (2019) while, inorganic fertilizer (NPK 15:15:15) was purchased from the open market and analyzed before use.

\section{Biodegradation experiment}

The collected soil was air dried and passed through $2 \mathrm{~mm}$ sieve. The experimental design employed was completely randomized. The experiment consisted of 9 treatments replicated 3 times. Each treatment contained $500 \mathrm{~g}$ of the sieved soil in empty plastic water bottles. The treatments were contaminated artificially with 3 levels $[5,10$ and $15 \%(\mathrm{v} / \mathrm{w})]$ of spent engine oil (SEO). The contaminated soil samples were stirred to ensure a homogenous mixture of soil and SEO. It was left undisturbed for 14 days to allow the volatilization of toxic components of the SEO following the recommendation of Abioye et al. (2012). Fluconazole $(0.1 \mathrm{ml})$ was added to each experimental bottle to avert the growth of fungi before the start of incubation assay. Subsequently, $50 \mathrm{~g}$ of each bio-stimulant (compost and NPK 15:15:15) was introduced into each SEO contaminated soil. Throughout the incubation assay period that lasted for four weeks, $2 \mathrm{ml}$ of distilled water was added to each experimental bottle once in a week as outlined by Abioye et al. (2012). Periodic sampling from each plastic bottle was carried out once in two weeks to determine the $\mathrm{pH}$, temperature, bacterial population density, electrical conductivity (EC) and total petroleum hydrocarbon (TPH).

\section{Preparation of mineral salt medium (MSM)}

A medium having the essential nutrients (potassium, magnesium, sodium, phosphorus and ammonium salts) required by the targeted bacteria for their optimum growth was prepared by dissolving $0.1 \mathrm{~g} \mathrm{NaCl}, 1.8 \mathrm{~g} \mathrm{KH}_{2} \mathrm{PO}_{4}, 0.2 \mathrm{~g}$ $\mathrm{MgSO}_{4} .7 \mathrm{H}_{2} \mathrm{SO}_{7}, 0.01 \mathrm{~g} \mathrm{FeSO}_{4} .7 \mathrm{H}_{2} \mathrm{O}$ and $4.0 \mathrm{~g} \mathrm{NH}_{4} \mathrm{Cl}$ in one (1) liter of distilled water as described by Mukred (2008). The MSM was subsequently sterilized in the autoclave at $121^{\circ} \mathrm{C}$ for fifteen (15) minutes (min.) and later dispensed.

Determination of physicochemical properties of compost, unpolluted soil and SEO polluted soil

The physical and chemical analysis of the soil and compost were carried out in the Soil Science Laboratory of the Federal University Dutse. Physicochemical properties of unpolluted soil, SEO polluted soil and compost was estimated before the commencement of the biodegradation experiment. Organic carbon, cation exchange capacity (CEC), $\mathrm{pH}$, electrical conductivity (EC), moisture content, sand, silt, clay, soil texture, soil type, parent materials, total nitrogen, available phosphorous and soil mechanical analysis were determined following the procedures for soil analysis. Total Petroleum Hydrocarbon (TPH) content of the SEO was determined using the USEPA $1850 \mathrm{C}$.
Isolation procedure for spent engine oil degrading bacteria (SEODB)

Spent engine oil degrading bacteria were isolated using selective enrichment method. One $g$ each of the soil was weighed and suspended into three test tubes containing $9 \mathrm{ml}$ sterile distilled water. The mixture was vigorously shaken to give room for the formation of supernatant. Subsequently, $1 \mathrm{ml}$ of the supernatant was introduced into test tubes containing Mineral Salt Medium (MSM) overlaid with $0.5 \mathrm{ml}$ of spent engine oil each. The mixture in the test tubes was then shaken vigorously and allowed to settle. The test tubes were subsequently incubated at $37.3^{\circ} \mathrm{C}$ for 24 hours and bacterial growth in form of turbidity was looked out for. Bacterial growth observed after incubation was sub-cultured in three test tubes containing nutrient broth and incubated at $37.3^{\circ} \mathrm{C}$ for 48 hours. The nutrient broth was prepared according to the standard procedure described by the manufacturer (MICROGEN). After incubation of the test tubes, further subculturing was carried out using three nutrient agar plates. The nutrient agar was prepared according to the standard procedure described by the manufacturer. The nutrient agar plates were incubated at $37.3^{\circ} \mathrm{C}$ for 48 hours; the colonies that developed were observed and recorded. Distinct colonies were subsequently picked and transferred to other glass slides to form smears. Gram staining procedure was carried out according to Olutiola et al. (2000). The smear on the slide was subsequently flooded with crystal violet solution for sixty (60) seconds, and rinsed with water. All the cells turned purple and the smear was again flooded with Iodine for one minute. and the slide was rinsed with $75 \%$ alcohol until the crystal violet was completely washed off. It was subsequently counter stained with safaranin for one minute and finally rinsed with water. The slides were then viewed under an oil immersion objective.

Biochemical Tests for further Identification of Isolates

The choice made on the types of biochemical tests conducted on each of the already isolated and gram stained bacteria in this study were influenced by the procedures prescribed by Barrow and Feltham (1993) for the identification of such groups of bacteria based on their morphological attributes. Biochemical tests were done according to the procedures established by Cheesebrough (2000); Choopun et al. (2002); Ochei and Kolhatkar (2008); Wilson (2012); Hemraj et al. (2013); Himedia (2015); Pokhrel (2015); Microbeonline (2019).

\section{Statistical Analysis}

All data collected were subjected to Proc. GLM of GenStat version 17. Significant means were separated using Duncan Multiple Range Test (DMRT) as described by Gomez and Gomez, (1984).

\section{RESULTS}

Physicochemical properties of compost, unpolluted soil and SEO polluted soil

Results obtained from the physicochemical properties of compost, unpolluted soil and SEO polluted soil are presented in Table 1. Higher values of the following parameters were obtained from compost: organic Carbon (48.22\%), Available Phosphorous (1.50 $\mathrm{mg} \mathrm{kg}^{-1}$ ) and SEB (321.43 $\left.\mathrm{cmol} \mathrm{kg}^{-1}\right)$. 
Table 1: Physicochemical properties of compost, unpolluted soil and SEO polluted soil.

\begin{tabular}{lccc}
\hline Parameters & Unpolluted soil & Polluted soil & Compost \\
\hline Moisture content & 2.08 & 6.6 & 2.02 \\
Ash content (\%) & - & - & 66 \\
pH (water) & 6.5 & 6.9 & 9.4 \\
Organic Carbon (\%) & 0.50 & 0.54 & 48.22 \\
Total Nitrogen & 0.04 & 0.07 & 5.84 \\
Available Phosphorous (mg kg-1) & 10.98 & 9.38 & 1.50 \\
EC(dS cm ${ }^{-1}$ ) & 0.88 & 1.26 & 8.89 \\
Exchangeable Bases (cmol kg $\left.{ }^{-1}\right)$ & & & 312.99 \\
Potassium & 0.21 & 0.08 & 4.70 \\
Calcium & 1.80 & 0.64 & 3.22 \\
Magnesium & 0.94 & 0.19 & 0.52 \\
Sodium & 0.55 & 0.18 & 321.41 \\
Sum of Exch. Bases & 3.51 & 1.09 & - \\
Particle size (g kg $\left.{ }^{-1}\right)$ & & & - \\
Clay & 110 & 120 & - \\
Silt & 330 & 80 & - \\
Sand & 580 & Loamy sand & \\
Textural class & Sandy loam & & \\
\hline
\end{tabular}

Isolation and biochemical identification of SEO utilizing bacteria

Enrichment of nutrient broth and agar with MSM overlaid with SEO was adopted with a view to isolating SEO utilizing bacteria in this study has proved to be effective as four (4) distinct bacterial colonies were isolated. The following colonial characteristics observed on the TSA plates after incubation are presented in Table 2. Having conducted suitable biochemical tests, the possible bacteria were isolated and depicted in Table 3.

Table 2: Morphological characteristics and identification of bacterial isolates.

\begin{tabular}{lcc}
\hline Colonial characteristic & Gram staining & Bacteria \\
\hline Transparent colonies & Gram positive cocci in clusters & Staphylococcus aureus \\
Milky colonies & Gram negative rods & Pseudomonas aeruginosa \\
Scanty growth colonies & Gram positive rods & Bacillus cereus. \\
Greenish colonies with moderate growth & Gram positive cocci in chains & Streptococcus pyogenes \\
\hline
\end{tabular}

Effect of amendments on bacterial degradation of TPH Results obtained on the bacterial degradation of SEO contaminated soil indicate that the two bio stimulants significantly $(\mathrm{p}<0.05)$ enhanced TPH degradation as shown in Table 3. Specifically, at the second week, compost recorded more reduction (3963 $\mathrm{mg} \mathrm{kg}^{-1}$ ) representing 35\% degradation compared with inorganic fertilizer $\left(5421 \mathrm{mg} \mathrm{kg}^{-1}\right)$ representing $12 \%$ degradation on $5 \%$ SEO contamination level. Compost recorded the feat at the fourth week by enhancing the more reduction (866 $\mathrm{mg} \mathrm{kg}^{-1}$ ) compared with inorganic fertilizer. Thus in comparison with inorganic fertilizer that recorded $61.77 \%$ TPH reduction, compost had the highest level of TPH reduction across all weeks. Compost recorded the highest reduction of $82.44 \%$ in TPH concentration (1760) when compared with inorganic fertilizer (4024) of $52.12 \%$ reduction rate. 
Table 3: Effect of bio stimulant on TPH at the second week $\left(\mathrm{mg} \mathrm{kg}^{-1}\right)$.

\begin{tabular}{lccc}
\hline & \multicolumn{2}{c}{ Spent engine oil contamination levels (\%) at 2 weeks } \\
\cline { 2 - 4 } Bio stimulants & $\mathbf{5}$ & $\mathbf{1 0}$ & $\mathbf{1 5}$ \\
\hline Inorganic fertilizer & $5421^{\mathrm{b}}$ & $6396^{\mathrm{b}}$ & $7425^{\mathrm{b}}$ \\
Compost & $3963^{\mathrm{c}}$ & $4535^{\mathrm{c}}$ & $5674^{\mathrm{c}}$ \\
Control & $6152^{\mathrm{a}}$ & $8325^{\mathrm{a}}$ & $9952^{\mathrm{a}}$ \\
& Spent engine oil contamination levels at 4 weeks $^{2}$ & $4024^{\mathrm{b}}$ \\
Inorganic fertilizer & $2352^{\mathrm{b}}$ & $3985^{\mathrm{b}}$ & $1760^{\mathrm{c}}$ \\
Compost & $866^{\mathrm{c}}$ & $8322^{\mathrm{c}}$ & $9954^{\mathrm{a}}$ \\
Control & $6153^{\mathrm{a}}$ & & \\
\hline
\end{tabular}

Note: Means with the same superscripts are not significantly $(p<0.05)$ different.

The overall comparison of the bio-stimulatory influence of compost and inorganic fertilizer on bacterial degradation SEO showed compost to be more influential. At 5, 10 and 15\% SEO contamination levels, compost recorded 85.93, 82.44 and $82.31 \%$ TPH reductions while inorganic fertilizer recorded $61.77,52.12$ and $56.56 \%$ at 5,10 , and $15 \%$ SEO contamination levels in this study respectively.

Effect of temperature on bacterial degradation of SEO Results obtained from the bacterial degradation of SEO contaminated soil indicate that the amendments had no significant effect on temperature change as it ranged between 26 and $27^{\circ} \mathrm{C}$ for both inorganic fertilizer and compost respectively. However, inorganic fertilizer had the highest temperature $\left(27^{\circ} \mathrm{C}\right)$ at the second week when compared to compost which recorded $26^{\circ} \mathrm{C}$ (Table 4). At the fourth week, the amendments enhanced the same temperature $\left(25.3^{\circ} \mathrm{C}\right)$ on all the SEO contamination levels compared with the control that recorded lower temperature (Fig. 1).

Table 4: Effect of bio stimulants on temperature $\left({ }^{0} \mathrm{C}\right)$.

\begin{tabular}{lccc}
\hline & \multicolumn{3}{c}{ Spent engine oil contamination levels (\%) at 2 weeks } \\
\cline { 2 - 4 } Bio stimulants & $\mathbf{5}$ & $\mathbf{1 0}$ & $\mathbf{1 5}$ \\
\hline Inorganic fertilizer & $27.00^{\mathrm{a}}$ & $27.00^{\mathrm{a}}$ & $27.00^{\mathrm{a}}$ \\
Compost & $26.00^{\mathrm{b}}$ & $26.00^{\mathrm{b}}$ & $26.00^{\mathrm{b}}$ \\
Control & $26.33^{\mathrm{ab}}$ & $26.67^{\mathrm{ab}}$ & $26.33^{\mathrm{ab}}$ \\
& & Spent engine oil contamination levels at 4 weeks & 25.33 \\
Inorganic fertilizer & 25.33 & 25.33 & 25.33 \\
Compost & 25.33 & 25.33 & 24.33 \\
Control & 24.33 & 24.33 & \\
\hline
\end{tabular}

Note: Means with the same superscripts are not significantly $(p<0.05)$ different.

Effect of pH on enhanced bacterial degradation of SEO

Results shown in Table 5 indicate that during the incubation assay, the average $\mathrm{pH}$ remained in the range of alkalinity $(7.8$ and 8.06) for treatments under the influence of compost as well as control. Slightly acidic values of 6.23 and 6.33 were obtained from under the influence of inorganic fertilizer. This acidic $\mathrm{pH}$ values obtained further confirms a well-known fact that inorganic fertilizers especially $\mathrm{N}$-containing fertilizers decrease $\mathrm{pH}$ of soils.

Table 5: Effect of bacterial degradation on pH.

\begin{tabular}{lccc}
\hline & \multicolumn{3}{c}{ Spent engine oil contamination levels (\%) } \\
\cline { 2 - 4 } Bio stimulants & $\mathbf{5}$ & $\mathbf{1 0}$ & $\mathbf{1 5}$ \\
\hline Inorganic fertilizer & $6.23^{\mathrm{c}}$ & $6.33^{\mathrm{c}}$ & $6.33^{\mathrm{c}}$ \\
Compost & $7.87^{\mathrm{b}}$ & $7.93^{\mathrm{ab}}$ & $8.07^{\mathrm{ab}}$ \\
Control & $8.13^{\mathrm{ab}}$ & $7.67^{\mathrm{b}}$ & $8.67^{\mathrm{a}}$ \\
\hline
\end{tabular}

Note: Means with the same superscripts are not significantly $(p<0.05)$ different. 
It can be observed that inorganic fertilizer enhanced increment

Effect of electric conductivity on bacterial degradation of SEO

of EC from 11.23 to $12.00 \mathrm{dS} \mathrm{cm} \mathrm{cm}^{-1}$. This trend was recorded

Results obtained on the effect of EC on enhanced bacterial degradation of SEO contaminated soil are depicted in Table 6.

throughout the study as compared to compost which recorded EC values that ranged between 1.60 and $2.00 \mathrm{dS} \mathrm{cm}^{-1}$.

Table 6: Effect of bio stimulants on EC ( $\left.\mathrm{dS} \mathrm{cm}^{-1}\right)$.

\begin{tabular}{lccc}
\hline & \multicolumn{2}{c}{ Spent engine oil contamination levels at 2 weeks (\%) } \\
\cline { 2 - 4 } & $\mathbf{5}$ & $\mathbf{1 0}$ & $11.57^{\mathrm{a}}$ \\
\hline Inorganic fertilizer & $12.0^{\mathrm{a}}$ & $2.57^{\mathrm{b}}$ & $12.00^{\mathrm{a}}$ \\
Compost & $2.20^{\mathrm{bc}}$ & $0.60^{\mathrm{d}}$ & $3.10^{\mathrm{b}}$ \\
Control & $0.60^{\mathrm{ce}}$ & $0.60^{\mathrm{ce}}$ & $11.30^{\mathrm{a}}$ \\
& \multicolumn{2}{c}{ Spent engine oil contamination levels at 4 weeks } & $1.60^{\mathrm{d}}$ \\
Inorganic fertilizer & $11.30^{\mathrm{a}}$ & $11.23^{\mathrm{b}}$ & $1.60^{\mathrm{d}}$ \\
Compost & $1.70^{\mathrm{c}}$ & $0.40^{\mathrm{e}}$ & $0.30^{\mathrm{f}}$ \\
Control & $0.30^{\mathrm{f}}$ & & \\
\hline
\end{tabular}

Note: Means with the same superscripts are not significantly $(p<0.05)$ different.

Effect of amendments on bacterial population density Results obtained from the estimation of hydrocarbon utilizing bacterial (HUB) population density in this study indicate that compost and inorganic fertilizer enhanced significant $(\mathrm{P}<0.05)$ increment of the bacterial population on $5 \%$ SEO contamination level at the second week (Table 7). The HUB count in 5\% SEO contamination soil stimulated with compost was higher ( $\left.313 \mathrm{cfu}^{-1}\right)$ in comparison with those stimulated with NPK fertilizer (205 $\left.\mathrm{cfu} \mathrm{g}^{-1}\right)$. Specifically, at the fourth week, compost enhanced HUB within the range of $0.626 \times 10^{3}$ to $0.674 \times 10^{3} \mathrm{cfu} \mathrm{g}^{-1}$.

Table 7: Effects of bio stimulants on microbial population density (cfu/g).

\begin{tabular}{|c|c|c|c|}
\hline \multirow[b]{2}{*}{ Bio stimulants } & \multicolumn{3}{|c|}{ Spent engine oil contamination levels $(\%)$ at 2 weeks } \\
\hline & 5 & 10 & 15 \\
\hline Inorganic fertilizer & $205.3^{\mathrm{b}}$ & $215.3^{\mathrm{b}}$ & $146.3^{\mathrm{c}}$ \\
\hline Compost & $313.3^{\mathrm{a}}$ & $341.3^{\mathrm{a}}$ & $320.0^{\mathrm{a}}$ \\
\hline Control & $196.0^{\mathrm{c}}$ & $201.3^{\mathrm{b}}$ & $191.3^{\mathrm{b}}$ \\
\hline \multicolumn{4}{|c|}{ Spent engine oil contamination levels at 4 weeks } \\
\hline Inorganic fertilizer & $412^{\mathrm{c}}$ & $434^{\mathrm{b}}$ & $297^{\mathrm{b}}$ \\
\hline Compost & $626^{\mathrm{a}}$ & $674^{\mathrm{a}}$ & $638^{\mathrm{a}}$ \\
\hline Control & $572^{\mathrm{b}}$ & $393^{c}$ & $292^{\mathrm{b}}$ \\
\hline
\end{tabular}

Note: Means with the same superscripts are not significantly $(p<0.05)$ different.

\section{DISCUSSION}

Findings from this study suggest that the topsoil containing SEO may be largely influenced by the presence decayed organic matter and the presence of oxygen containing functional groups needed for microbial metabolism. Similar bacteria isolated and identified biochemically in this study have been reported by Diaz-Ramirez et al. (2013); Kawo and Faggo (2017); Yahaya and Bappa (2019).

The reductions in the TPH content of the soil recorded in this study are in line with the results of Maryam and Ujah (2016); Kawo and Faggo (2017). Similar reductions in TPH of contaminated soils under the influence of organic amendments on bacterial degradation have been reported by Atagana (2008); Abioye et al. (2012); Hamzah et al. (2014); Bada et al. (2019). These results indicated that compost has a high enhancement capability in stimulating bacterial biodegradation of SEO contaminated soil. The feat that inorganic fertilizer achieved in this study is in concord with the finding of Cooney (1984) who reported that the highest degradation rates generally occur in the range $30-40^{\circ} \mathrm{C}$ in soil environment. More so, Venosa and Zhu (2003) reported that ambient temperature of the environment affected both the properties of spilled oil and the activity of microorganisms.

The $\mathrm{pH}$ values recorded in this study are in agreement with the report of the study conducted by Walker and Kieth (1992). Again, as observed in this current study, the fluctuations in the $\mathrm{pH}$ have been discussed by Prescott et al. (2002), as an indication of possible utilization of pollutants of concern by the bacteria present therein. It was also observed that compost enhanced lower EC compared to inorganic fertilizer in this study. Microorganisms are known to adapt to a certain range of salinity. APHA (1992) and Hach Company (1992), observed certain ranges of EC that are easily adaptable to by microorganisms. Exceeding this range may lead to a negative impact on microorganisms with a consequential death effect. Following the observation made by Odu et al. (1985), the introduction of inorganic fertilizer to soils increased the soluble salt-content of the soil leading to a general increase in the EC as recorded in this study.

The overall results from the estimate of HUB on 5, 10 and $15 \%$ SEO contaminated soil indicated that compost enhanced higher HUB thereby influencing bacterial degradation than those stimulated with inorganic fertilizer. These results support the submission of Jorgensen et al. (2000), on the capability of 
organic amendments' enhanced bioremediation project in recording higher HUB compared to inorganic amendments. According to Ijah and Antai (2003), the ability of organic fertilizer materials to enhance desirable hydrocarbon degradation might be due to their ability in neutralizing toxic effects of hydrocarbon by improving soil physicochemical properties appreciably.

\section{CONCLUSION}

This study revealed that supplementation of SEO contaminated soil with compost and inorganic fertilizer significantly enhanced the rate of bacterial degradation within the period of 4 weeks. The results obtained on the bacterial degradation of the soil contaminated with 5 and $15 \%$ SEO enhanced with compost indicated that at the fourth week, $86 \%$ bacterial degradation of SEO bacterial degradation was attained. The SEO contaminated soil stimulated with inorganic fertilizer recorded the lowest rate of bacterial degradation on 5, 10 and $15 \%$ SEO contamination levels respectively. Inorganic fertilizer recorded the highest temperature range favorable for bacterial degradation compared to compost in this study. However, compost enhanced the preferred biodegradation $\mathrm{pH}$ compared to inorganic fertilizer. Electrical conductivity values obtained under the influence of compost in this study were favorable for bacterial degradation SEO. Bacterial population density did increase under the influence of compost compared to the values recorded under the influence of inorganic fertilizer. The employment of organic fertilizer for hydrocarbon bioremediation project in lieu of other forms of enhancement is recommended owing to the feat it attained in this study. Again, the adoption of compost generated from waste materials most especially those of organic origin is recommended due to the fact that they are cheap, environment friendly and can be locally sourced.

\section{REFERENCES}

Abioye, O.P., Agamuthu, P. and Abdul-Aziz, R.A. (2012). Biodegradation of used motor oil using organic waste amendment. Hindawi Publishing Corporation. Biotechnol. Res. Int., Article ID 587041. http://downloads.hindawi.com/archive/2012/587041.pdf

Adeleye, A.O., Yerima, M.B., Nkereuwem, M.E., Onokebhagbe, V.O., Shiaka, P.G., Amoo, F.K. and Adam, I.K. (2019). Effect of organic amendments on the decontamination potential of heavy metals by Staphylococcus aureus and Bacillus cereus in soil contaminated with spent engine oil. Novel Res. Microbiol. J., 3 (5): 471-484.

APHA (1992). Standard methods for the examination of water and wastewater. American Public Health Association. 18th Edition. Washington, DC.

Atagana, H.I. (2008). Compost bioremediation of hydrocarbon-contaminated soil inoculated with organic manure. African Journal of Biotechnology. 7 (10): 1516-1525

Bada, B.S., Egbeja, T.I., Arowolo, T.A. and Obuotor, T.M. (2019). Degradation of total petroleum hydrocarbon in petroleum products-contaminated soil using pig dung. West African Journal of Applied Ecology, 27 (2): 1 - 15.
Barrow, G.I. and Feltham, R.K.A. (1993). Cowan and steel's manual for the identification of medical bacteria. 3rd Edition. Cambridge University Press.

Cheesebrough, M. (2006). District laboratory practice in tropical countries, part II. 2nd Ed. New York: Cambridge University Press. Chapter 7. 38-54.

Choopun, N., Louis, V., Huq, A. and Colwell, R.R. (2002). Simple procedure for rapid identification of vibrio cholera from the aquatic environment. Appl. Environ. Microbiol.: 995-998.

Cooney, J.J. (1984). The fate of petroleum pollutants in fresh water ecosystems. In Petroleum Microbiology, R. M. Atlas, Ed., 399-434: Macmillan: New York: NY: USA.

Díaz-Ramírez, I., Escalante-Espinosa, E., Schroeder, R.A., Fócil-Monterrubio, R. and Ramírez-Saad, H., (2013). Hydrocarbon biodegradation potential of native and exogenous microbial inocula in Mexican tropical soils, biodegradation of hazardous and special products, Rolando Chamy and Francisca Rosenkranz, IntechOpen.

https://www.intechopen.com/books/biodegradation-ofhazardous-and-special-products/hydrocarbon-biodegradationpotential-of-native-and-exogenous-microbial-inocula-in$\underline{\text { mexican-tropical-s }}$

Ebakota, O.D., Osarueme, J.O., Gift, O.N., Odoligie, I. and Joseph, O.O. (2017). Isolation and characterization of hydrocarbon-degrading bacteria in top and subsoil of selected mechanic workshops in Benin City metropolis, Nigeria. $J$. Appl. Sci. Environ. Manage., 21 (4): 641-64.

Farag, S. and Soliman, N.A. (2011). Biodgradation of crude petroleum oil and environmental pollutants by Candida tropicalis strain. Braz. Arch. Biol. Technol., 54 (4): 821 - 830

Funmilayo, D., Aneyo, I. and Shobowale, N. (2016). Stimulated biodegradation of waste lubicating oil in soil, using water hyacinth and goat droppings. J. Environ. Occup. Sci., 5 (2): 47-52.

Gomez, K.A. and Gomez, A.A. (1984). Statistical procedure for Agricultural Research (2ed). John Wiley and Sons, New York, U.S.A, pp.: 680.

Hach Company (1992). Hach water analysis handbook. 2nd ed. Loveland, CO.

https://www.hach.com/wah.

Hamzah, A., Chia-Wei, P., Pek-Hoon, Y. and Nurul, H. (2014). Oil palm empty fruit bunch and sugarcane bagasse enhance the bioremediation of soil artificially polluted by crude oil. S. Sed. Con., 23 (7): 751-762.

Hemraj, V., Diksha, S. and Avneet, G. (2013). A review on commonly used biochemical test for bacteria. Innovare J. Life Sci., 1(1): 1-7.

Himedia (2015). Technical data. Gluconate test medium. http://himedialabs.com/TD/M483.pdf 
Jain, K. and Bajpai, V. (2012). Biotechnology of bioremediation - a review. Int. J. Environ. Sci., 3(1): 535 549.

Jorgensen, K.S., Puustinen, J. and Suortti, A.M. (2000). Bioremediation of petroleum hydrocarbon contaminated soil by composting in biopiles. Environ. Pollut., 107(2): 245-254.

Ijah U.J.J. and Antai, S.P. (2003). The potential use of chickendrop micro-organisms for oil spill remediation. Environmentalist, 23 (1): 89-95.

Kamaluddeen, K., Yerima, M.B., Abu, T.R. and Deeni, Y. (2016). Biostimulatory effect of processed sewage sludge in bioremediation of engine oil contaminated soils. Int. J. Sci. Technol. Res., 5(2): 203-207.

Kawo, A.H. and Faggo, A.A. (2017). Enhanced removal of crude oil in soil by co-culture of Bacillus subtilis and Pseudomonas aeruginosa Isolated from contaminated soil in Kano State, Nigeria. BAJOPAS, 10 (1): 423-427.

Maryam, L.R.S. and Ijah, U.J.J. (2016). Enhanced removal of crude oil in soil by mixed culture of Bacillus megaterium UL05 and Pseudomonas aeruginosa UL07. Int. J. Environ. Biorem. Biodegradation, 4 (1): 8-12.

Microbeonline (2019). Medical microbiology guide. voges proskauer (VP) test: principle, procedure and results. https://microbeonline.com/voges-proskauer-testprinciple-procedure-results/

Mukred, A.M., Hamid, A.A., Hamzah, A. and Yusoff, W.M.W. (2008). Growth enhancement of effective microorganisms for bioremediation of crude oil contaminated waters. Pak. J. Biol. Sci., 11 (13): 1708-1712.

Nievas, M.L, Conmendatorea, M.G., Esteves, J.L. and Bucal'a, V. (2007). Biodegradation pattern of hydrocarbons from a fuel oil-type complex residue by an emulsifier-producing microbial consortium. J. Hazard. Mater., 154 (1-3): 96-104.

Ochei, J.O. and Kolhatkar, A.A. (2008). Medical laboratory science: Theory and practice. Tata McGraw Publishing Company Limited, New York, Seventh Edition, pp 820-821.

Odu, C.T.I., Esuruoso, O.F., Nwoboshi, L.C. and Ogunwale, J.A. (1985). Environmental study of the Nigerian Agip oil company operational areas. In proceedings of the soils and fresh water vegetation conference, Milan, Italy. Pp 99. . Zhang, Z.G., Hou, Z., Yang, C., Mac, W.Z., Sun, B., He, X., Tang, H. and $\mathrm{Xu}, \mathrm{P}$. (2010). Characterization of biotechnological potential of Olutiola, P.O. Famurewa, O. and Sonntag, H.G. (2009)etroleum degrading bacterial isolated from oil-contaminated soils. Introduction to Microbiology, (2nd edn), HeidelberBiorsour. Technol., 10: 8452-8462.

Nigeria, Pp 267.

Osazee, E., Yerima, M.B. and Shehu, K. (2015). Bioremediation of crude oil contaminated soils using cow dung as bioenhancement agent. Ann. Biol. Sci., 3(2): 8-12.
Pala, M.D., De Carvalho, D., Pinto, J.C. and Sant Anna Jr, G.L. (2006). A suitable model to describe bioremediation of a petroleum-contaminated soil. J. Int. Biodeter. and Biodegr., 58 (6): 254-260.

Pokhrel (2015). test- principle, procedure, result interpretation and limitation.

http://microbiologynotes.com/cetrimide-test-principle-

procedure-result-interpretation-and limitation/

Prescott, L.M., Harley, J.P. and Klein, D.E. (2002). Microbiology. 5th Edition, Amazon Inc., ISBN10: 0072320419

https://www.amazon.com/Microbiology-Fifth-Lansing-MPrescott/dp/0072320419

Sathishkumar, M., Binupriya, A.R., Baik, S.H. and Yung, S.E. (2008). Biodegradation of crude oil by individual bacterial strains and a mixed bacterial consortium isolated from hydrocarbon contaminated areas. Clean, 36 (1): 92-96.

United State Environmental Protection Agency (USEPA) (2003). Method 8015C (SW-846): Non-halogenated organics using GC/FID. Revision 4. Washington, DC.

https://www.epa.gov/esam/epa-method-8015d-sw-846nonhalogenated-organics-using-gcfid

Venosa, A.D. and Zhu, X. (2003). Biodegradation of crude oil contaminating marine shorelines and freshwater wetlands. Spill Sci. Technol. Bull., 8 (2): 163-178.

Walker, M.H. and Keith, L.H. (1992). EPA's pesticide fact sheet database. Lewis Publisher, Chelsea, MI.

Wilson, G. (2012). Virtual unknown microbiology internet edition.

https:/www.vumicro.com/vumie/help/VUMICRO/Lactose_Fer mentation Test.html

Yahaya, S. and Bappa, A.M. (2019). Assessment of biodegradation potential on different soil particles. $N . J$. Microbiol., 33 (2): 4423-4433.

Yerima, M.B., Agina, S.E., Zuru, A.A., Venil, K., Farouq, A.A., Maishanu, H.M., Shinkafi, A.L. and Kashim, Z.A. (2011). Assessment of biostimulation using some organic wastes in bacterial reclamation of crude oil contaminated agricultural soil. J. Sustainable Dev. Environ. Prot., 1 (1): 69-76. 